\title{
Peran dan Kontribusi Curahan Waktu Kerja Wanita Pada Usaha Pembesaran Ikan Patin (Pangasius sp) Dalam Kolam (Studi Kasus Di Desa Pudak Kecamatan Kumpeh Ulu Kabupaten Muaro Jambi)
}

\author{
*1Asmaida dan ${ }^{1}$ Rogayah \\ Program Studi Agribisnis Fakultas Pertanian Universitas Batanghari \\ J1. Slamet Riyadi-Broni, Jambi. 36122. Tel. +6274160103 \\ ${ }^{*}$ e-mail korespondensi : asmaida.syandri@yahoo.co.id
}

\begin{abstract}
Research was carried out in Pudak Kumpeh Ulu village, Muaro Jambi District. Its goal was 1). Describing the female's role in the pond's catfish farming. 2). To Calculate amount of working duration of female and male in catfish farming in a pond. 3). Analyzing the contributions of female's working duration on a catfish farming in a ponds. The research method used a survey method. It also used a primary and secondary data, with cross section data type based on ratio scale measurement. The population were amount of housewife who did an fish enlargement of the catfish farming in a pond. There were 33 Samples that chosen randomly ones. The descriptive analysis method was used in this research. The results showed that : 1). The role of female on the catfish farming in the pond showed high enough category, females were almost completely involved in pond preparation activities (drying ponds, weaning, fertilization and water giving), seed spreading, feeding, pondcleaning, and harvesting. 2). The everage of female's work duration on the catfish farming in the pond e.g. 31.48 hours/period in the pool preparation activities (pool drying, sowing, fertilization and water giving), 4.12 hours/period in seed spread, 338.18 hours/period for feeding, 30.91 hours/period in pool- cleaning, and harvesting for 3.36 hours/period. 3). It was 91.17\% contribution of female's work duration on the catfish farming in the pond and the remaining as men work duration was $8.83 \%$
\end{abstract}

Keywords: work duration, female labor, Catfish

Abstrak. Penelitian dilaksanakan di Desa Pudak Kecamatan Kumpeh Ulu Kabupaten Muaro Jambi. Tujuan penelitian ini adalah 1).Mendeskripsikan peranan wanita pada usaha pembesaran ikan patin dalam kolam. 2). Menghitung besarnya curahan waktu kerja wanita dan pria pada usaha pembesaran ikan patin dalam kolam. 3).Menganalisis besarnya kontribusi curahan waktu kerja wanita pada usaha pembesaran ikan patin dalam kolam. Metode penelitian menggunakan metode survey. Sumber data primer dan data sekunder, jenis data cros section berdasarkan skala pengukuran rasio. Populasi adalah ibu rumah tangga yang melakukan usaha pembesaran ikan patin dalam kolam. Sampel berjumlah 33 orang yang dipilih secara acak. Metode analisis data menggunakan metode deskriptif. Hasil penelitian menunjukan 1).Peranan wanita pada usaha pembesaran ikan patin dalam kolam cukup tinggi, wanita hampir sepenuhnya terlibat pada kegiatan persiapan kolam (pengeringan kolam, pengapuran, pemupukan dan pengisian air), penebaran benih, pemberian pakan, pembersihan pematang kolam, dan panen. 2).Rataan curahan waktu kerja wanita pada usaha pembesaran ikan patin dalam kolam pada kegiatan persiapan kolam (pengeringan kolam, pengapuran, pemupukan dan pengisian air) selama 31,48 jam/periode produksi, penebaran benih selama 4,12 jam/periode produksi, pemberian pakan selama 338,18 jam/periode produksi, pembersihan pematang kolam 30,91 jam/periode produksi, dan panen selama 3,36 jam/periode produksi. 3).Kontribusi curahan waktu kerja wanita pada usaha pembesaran ikan patin dalam kolam sebesar 91,17\% dan sisanya 8,83\% adalah curahan waktu kerja pria."

Kata kunci: Curahan Waktu, Tenaga Kerja Wanita, Ikan Patin

\section{PENDAHULUAN}

Ikan patin (Pangasius sp) merupakan komoditas unggulan Provinsi Jambi. Kabupaten Muaro Jambi adalah penghasil produksi budidaya ikan patin yang terbesar yaitu sebesar 1.448,5 ton atau 79,94\% dari total produksi ikan Provinsi Jambi. Ikan patin adalah komoditi yang mempunyai pasar yang baik dan besar di dalam negeri maupun di mancanegara dengan harga yang relatif tinggi dan stabil. Di samping itu budidaya ikan patin pada tahun-tahun belakangan ini juga mengalami kemajuan yang pesat dari segi teknis budidaya sehingga telah dicapai peningkatan produk yang signifikan dibanding produksi jenis komoditas utama perikanan yang lain (Dinas Kelautan dan Perikanan, 2019).

Ikan patin juga sangat diminati konsumen, karena konsumen menilai bahwa ikan patin sehat untuk dikonsumsi, mengandung nilai gizi yang sangat baik untuk kesehatan, rasanya enak, mudah dalam pengolahannya, mudah didapatkan, tingkat kesegarannya tinggi, dan harga relatif murah (Asmaida, at all, 2019).

Di Kabupaten Muaro Jambi, peranan wanita disektor publik yang terbesar berada pada sektor pertanian, perkebunan dan perikanan yaitu sebesar 56,18\%. Sedangkan pada sektor industri hanya sebesar 7,95\%. Besarnya persentase jumlah wanita yang bekerja di sektor pertanian, perkebunan dan perikanan dimungkinkan karena sektor pertanian, perkebunan dan perikanan tidak memerlukan keahlian khusus ataupun tingkat pendidikan tertentu yang biasanya tidak dimiliki oleh kebanyakan wanita terutama dipedesaan (BPS Provinsi Jambi, 2019). Selanjutnya wanita bekerja karena untuk membantu perekonomian rumah tangga dan cendrung memilih bekerja di sektor informal agar dapat membagi waktu antara pekerjaan dan keluarga, kondisi ini sangat berbeda dengan sektor formal dimana wanita terpaksa harus mengurangi aktivitasnya dirumah tangga dan 
mempunyai keahlian khusus. Hal ini ditujukan untuk memperoleh pendapatan serta aktivitas sosial yang dilakukan dalam masyarakat (Asyiek, 2009 dalam Kurniati, 2016).

Dalam sektor perikanan yaitu pada budidaya ikan patin petani bekerja dengan menggunakan tenaga kerja keluarga dan luar keluarga (upahan). Para pekerja tersebut terdiri dari tenaga kerja pria dan tenaga kerja wanita. Sebagai bagian anggota keluarga, tenaga kerja wanita mempunyai andil didalam memperoleh pendapatan untuk mewujudkan kesejahteraan keluarganya dan juga dapat memberikan sumbangan tenaganya didalam kegiatan usaha budi daya ikan patin guna peningkatan pendapatan keluarganya. Curahan waktu kerja wanita dalam usaha budidaya ikan patin di Desa Pudak Kecamatan Kumpeh Ulu Kabupaten Muaro Jambi dipengaruhi oleh tingkat pengetahuan wanita tani dan kepercayaannya terhadap usaha budidaya ikan patin tersebut (Asmaida, 2009).

Di Desa Pudak Kecamatan Kumpeh Ulu Kabupaten Muaro Jambi, pada sektor perikanan wanita sebagian besar bekerja sebagai pekerja keluarga, membantu suaminya dengan tidak meninggalkan perannya sebagai seorang ibu rumah tangga dan tidak ada aturan yang mengikat. Kendatipun relatif besarnya keterlibatan wanita di pedesaan dalam kegiatan-kegiatan perikanan tersebut, namun peranan mereka jarang diperhitungkan dalam rangka mengambil kebijakan pembangunan perikanan. Berbagai program peningkatan ekonomi pedesaan lebih banyak ditujukan kepada kaum pria di pedesaan, demikian pula halnya dengan program penyebaran informasi perikanan.

Berdasarkan uraian tersebut di atas makaperlu kiranya dilakukan penelitian dengan judul "Peran Dan Kontribusi Curahan Waktu Kerja Wanita Pada Usaha Pembesaran Ikan Patin (Pangasius sp) Dalam Kolam (Studi Kasus di Desa Pudak Kecamatan Kumpeh Ulu Kabupaten Muaro Jambi)”.

\section{METODOLOGI PENELITIAN}

Penelitian dan pengambilan data dilapangan dilaksanakan pada bulan Februari sampai Juli 2020, di Desa Pudak, Kecamatan Kumpe Ulu, Kabupaten Muaro Jambi, Provinsi Jambi. Jenis data yang digunakan dalam penelitian ini adalah jenis data cross section dengan skala ukur jenis data rasio. Sumber data terdiri dari data primer dan data sekunder. Data primer berupa data yang diambil melalui wawancara langsung dengan responden yaitu sebanyak 33 rumag tangga petani (RTP), dengan cara menggunakan daftar kuesioner tentang kegiatan usaha pembesaran ikan patin dalam kolam. Pengumpulan data sekunder dilakukan dengan cara studi pustaka menyangkut profil desa tempat dilakukannya penelitian yang diperoleh dari Kantor Kepala Desa Pudak, Kantor BPS Provinsi Jambi dan juga dari sumber-sumber lain yang dapat dipertanggungjawabkan. Penelitian menggunakan metode survei. Menurut Silalahi, U. 2010, bahwa survei adalah suatu usaha untuk mendapatkan dan mengumpulan data dan informasi dari berbagai sumber.

Data penelitian yang telah dikumpulkan di lapangan dalam kegiatan usaha budidaya ikan patin dianalisis menggunakan tabulasi, yaitu untuk menghitung rata-rata curahan jam kerja dan persentase alokasi kegiatan yang dilaksanakan tenaga kerja wanita pada usaha budidaya ikan patin kolam selanjutnya dianalisis secara deskriptif. Sedangkan untuk menghitung kontribusi wanita tenaga kerja pada usaha budidaya ikan patin dalam kolam dihitung dengan menggunakan rumus (Suratiyah, 2003) sebagai berikut: "K $=\{(\mathrm{TKw} / \mathrm{TKt}) * 100 \%\}$

Keterangan :

$\mathrm{K} \quad=$ Kontribusi (\%)

TKw = Tenaga Kerja Wanita pada Usaha Pemberasan Ikan Patin Dalam Kolam (Jam/Periode Produksi)

TKt $=$ Total Tenaga Kerja pada Usaha Pembesaran Ikan Patin Dalam Kolam (Rp/Periode Produksi)"

\section{Karakteristik Responden}

\section{HASIL PENELITIAN}

Pada penelitian ini yang menjadi responden adalah wanita tani. Wanita tani ini adalah masyarakat wanita yaitu ibu rumah tangga yang memiliki atau melakukan usaha pembesaran ikan patin dalam kolam sebagai salah satu sumber pendapatan untuk membantu suami dalam meningkatkan ekonomi rumah tangganya. Karakteristik responden ini mampu menggambarkan potensi wanita tani. Potensi tersebut adalah kemampuan yang dimiliki wanita tani dalam melaksanakan kegiatan usahataninya. Dari hasil penelitian terhadap wanita tani sampel, maka dapat dijelaskan karakteristik wanita tani sampel yang meliputi, umur wanita tani, tingkat pendidikan wanita tani, jumlah anggota keluarga wanita tani, pengalaman berusaha dan keadaan usaha ikan patin kolam.

\section{A. Umur}

Umur merupakan faktor yang penting dalam proses produksi usaha pembesaran ikan patin dalam kolam. Umur dapat mempengaruhi kemampuan wanita tani dalam mengelola usaha pembesaran ikan patin dalam kolam, baik dalam bekerja, berfikir dan mengambil keputusan. Secara umum seseorang yang berumur muda dan sehat mempunyai kemampuan fisik yang lebih kuat dari seseorang yang berumur tua. Orang muda lebih cepat menerima inovasi baru dan lebih berani menanggung resiko dibandingkan dengan orang tua (Soeharjo dan Patong, 1973)."Dari 
Asmaida dan Rogayah. Peran dan Kontribusi Curahan Waktu Kerja Wanita Pada Usaha Pembesaran Ikan Patin (Pangasius sp) Dalam Kolam (Studi Kasus Di Desa Pudak Kecamatan Kumpeh Ulu Kabupaten Muaro Jambi)

hasil penelitian terhadap 33 orang wanita tani yang dijadikan sebagai responden di daerah penelitian, umur wanita tani berkisar antara $37-60$ tahun, seperti terlihat pada Tabel 1 .

Tabel 1. Distribusi Frekuensi Wanita Tani Berdasarkan Kelompok Umur Di Desa Pudak

\begin{tabular}{lccc}
\hline No & $\begin{array}{c}\text { Distribusi umur wanita tani } \\
\text { (Tahun) }\end{array}$ & $\begin{array}{c}\text { Frekuensi } \\
(\text { Orang) }\end{array}$ & $\begin{array}{c}\text { Persentase } \\
(\%)\end{array}$ \\
\hline 1. & $37-40$ & 7 & 21,21 \\
2. & $41-44$ & 2 & 6,06 \\
3. & $45-48$ & 7 & 21,21 \\
4. & $49-52$ & 10 & 30,30 \\
5. & $53-56$ & 5 & 15,15 \\
6. & $57-60$ & 2 & 6,06 \\
\hline & Jumlah & 33 & 100,00 \\
\hline
\end{tabular}

Sumber : Olahan data primer, 2020

Berdasarkan Tabel 1 terlihat bahwa persentase umur terbesar wanita tani di daerah penelitian adalah $49-52$ tahun yaitu sebesar 30,30\% (10 orang) dan persentase terkecil ada pada kelompok umur $41-44$ tahun dan $57-60$ tahun yaitu masing-masing sebesar $6,06 \%$ (2 orang) dari jumlah sampel, sedangkan rata - rata umur wanita tani sampel adalah 48 tahun.

Kondisi ini menggambarkan bahwa wanita tani usaha pembesaran ikan patin dalam kolam berada pada umur yang masih produktif. Menurut Hernanto, (1996) bahwa usia produktif berada pada usia 15 - 50 tahun. Melihat angka tersebut berarti mayoritas wanita tani adalah wanita tani muda yang potensial sebagai tenaga kerja dalam berusaha budidaya ikan patin dalam kolam, karena pada usia tersebut wanita tani mempunyai kemampuan fisik yang kuat dan dinamis.

\section{B. Tingkat Pendidikan}

Tingkat pendidikan wanita tani akan mempengaruhi cara berfikir yang diterapkan dalam usaha pembesaran ikan patin dalam kolam yaitu kemampuan mengelola usaha pembesaran ikan patin dalam kolam dan menerima teknoligi baru. Wanita tani yang pendidikanya rendah pada umumnya akan menutup diri terhadap inovasi baru. Tingkat pendidikan wanita tani diukur berdasarkan tingkat pendidikan formal yang pernah dilaluinya. Salah satu indikator yang dapat digunakan untuk mengetahui kualitas sumber daya manusia adalah tingkat pendidikan penduduk, sesuai dengan pendapat Sumardi, et al (1997), kemajuan suatu wilayah ditentukan beberapa faktor penting yang mencakup kualitas sumber daya manusia.

Rendahnya tingkat pendidikan wanita tani bukan berarti bahwa wanita kurang terbuka dalam menerima dan menerapkan teknologi baru yang dianjurkan. Hal ini dapat dilihat bahwa wanita tani telah mengenal dan menggunakan teknologi dengan baik dalam melaksanakan usaha pembesaran ikan patin dalam kolam. Untuk mengetahui distribusi berdasarkan tingkat pendidikan formal wanita tani, seperti terlihat pada Tabel 2.

Tabel 2. Distribusi Frekuensi Wanita Tani Berdasarkan Tingkat Pendidikan di Desa Pudak

\begin{tabular}{cccc}
\hline No & $\begin{array}{c}\text { Distribusi Tingkat Pendidikan } \\
\text { (Formal) }\end{array}$ & $\begin{array}{c}\text { Frekuensi } \\
\text { (Orang) }\end{array}$ & $\begin{array}{c}\text { Persentase } \\
(\%)\end{array}$ \\
\hline 1. & Tamat SD sederajat & 16 & 48,48 \\
2. & Tamat SLTP sederajat & 14 & 42,42 \\
3. & Tamat SLTA sederajat & 3 & 9,09 \\
4. & Tamat Perguruan Tinggi & 0 & 0 \\
\hline & Jumlah & 33 & 100,00 \\
\hline
\end{tabular}

Sumber : Olahan data primer, 2020

Dari Tabel 2 di atas memperlihatkan tingkat pendidikan formal wanita tani usaha budidaya ikan patin kolam di Desa Pudak sebagaian besar tamat SD sederajat yaitu 16 orang $(48,48 \%)$. Dilihat dari tingkat pendidikannya secara keseluruhan, tingkat pendidikan wanita tani dapat dikatakan masih rendah. Rendahnya tingkat pendidikan wanita tani diduga bukan saja menjadi kendala dalam mengelola usaha pembesaran ikan patin dalam kolam tetapi juga wanita tani menjadi kurang dalam menerima teknologi baru."Rendahnya tingkat pendidikan wanita tani akan berpengaruh terhadap perencanaan dalam pengolahan usahataninya, hal ini akan mempengaruhi tingkat produksi yang dihasilkan petani tersebut. Soeharjo dan Patong (1993) menyatakan bahwa semakin tinggi tingkat pendidikan seseorang maka kemampuan petani untuk meningkatkan pengelolaan usahataninya akan lebih baik terutama dari segi teknologi baru, 
pemahaman budidaya dan pemasaran. Untuk mengatasi keadaan demikian, wanita tani di daerah penelitian tersebut sudah banya memperoleh pendidikan melalui jalur non formal seperti pelatihan atau penyuluhan sehingga kemampuannya dalam mengelola usahanya cukup baik. Hal ini sejalan dengan hasil penelitian Asmaida (2009), yang menyatakan Tingkat pengetahuan wanita tani dalam berusaha budidaya ikan patin kolam di Desa dikategorikan tinggi. Tingginya tingkat pengetahuan ini didapat dari pengalaman mereka membantu keluarga (suami) dan mengikuti penyuluhanpenyuluhan perikanan yang diberikan oleh PPL.

\section{Jumlah Anggota Keluarga}

Jumlah anggota keluarga akan mempengaruhi rasa tanggung jawab wanita tani terhadap kebutuhan keluarga. Dalam hal ini wanita tani akan berusaha sebatas kemampuannya untuk memenuhi kebutuhan tersebut. Semakin banyak anggota keluarga semakin besar pula dorongan bagi wanita tani untuk memenuhi kebutuhan keluarganya. Disamping itu jumlah anggota keluarga yang besar akan berpengaruh terhadap pengelolaan usahanya, hal ini disebabkan apabila pendapatan tidak mencukupi maka pengelolaan usaha juga akan terhambat karena akan lebih mengutamakan kebutuhan keluarganya. Adapun keadaan jumlah anggota keluarga wanita tani usaha pembesaran ikan patin dalam kolam dapat dilihat seperti pada Tabel 3.

Tabel 3. Distribusi Frekuensi Wanita Tani Berdasarkan Jumlah Anggota Keluarga di Desa Pudak

\begin{tabular}{cccc}
\hline No & $\begin{array}{c}\text { Distribusi jumlah anggota keluarga } \\
\text { (Orang) }\end{array}$ & $\begin{array}{c}\text { Frekuensi } \\
\text { (Orang) }\end{array}$ & $\begin{array}{c}\text { Persentase } \\
(\%)\end{array}$ \\
\hline 1. & 2 & 5 & 15,15 \\
2. & 3 & 9 & 27,27 \\
3. & 4 & 11 & 33,33 \\
4. & 5 & 8 & 24,24 \\
5. & 6 & 0 & 0,00 \\
6. & 7 & 0 & 0,00 \\
\hline
\end{tabular}

Sumber : Olahan data primer, 2020

Pada Tabel 3 terlihat bahwa wanita tani mempunyai persentase terbesar pada kelompok jumlah anggota keluarga 4 sebanyak 11 orang $(33,33 \%)$ dari jumlah wanita tani sampel, dengan rata-rata jumlah anggota keluarga 4 orang. Hal ini berarti bahwa wanita tani mempunyai anggota keluarga yang cukup besar dan dapat dijadikan sebagai sumber tenaga kerja keluarga pada usaha pembesaran ikan patin dalam kolam.

\section{Pengalaman Usaha Budidaya Ikan Patin Kolam}

Pengalaman berusaha budidaya ikan patin dalam kolam mempengaruhi terhadap tingkat usahataninya, dimana wanita tani tersebut mempunyai cara-cara tersendiri dalam melaksanakan usahanya. Dimana pengalaman berusaha budidaya ikan patin wanita tani di daerah penelitian yang terlama adalah 5 tahun dan yang terendah adalah 1 tahun. Untuk lebih jelasnya dapat dilihat pada Tabel 4.

Tabel 4. Distribusi Frekuensi Wanita Tani Berdasarkan Pengalaman Usaha Budidaya Ikan Patin dalam Kolam di Desa Pudak

\begin{tabular}{lccc}
\hline No & $\begin{array}{c}\text { Distribusi pengalaman usaha } \\
\text { (Tahun) }\end{array}$ & $\begin{array}{c}\text { Frekuensi } \\
(\text { Orang) }\end{array}$ & $\begin{array}{c}\text { Persentase } \\
(\%)\end{array}$ \\
\hline 1. & 12 & 4 & 12,12 \\
2. & 13 & 10 & 30,30 \\
3. & 14 & 7 & 21,21 \\
4. & 15 & 9 & 27,27 \\
5. & 16 & 1 & 3,03 \\
6. & 17 & 2 & 6,06 \\
\hline & Jumlah & 33 & 100,00 \\
\hline
\end{tabular}

Sumber : Olahan data primer, 2020

Pada Tabel 4 di atas terlihat bahwa pengalaman usaha budidaya ikan patin dalam kolam sebagaian besar berkisar antara 13 tahun yaitu sebanyak 10 Orang (30,30\%), sedangkan dilihat dari rata-rata pengalaman petani adalah 14 tahun. Hal ini menunjukan bahwa petani di Desa Pudak berpengalaman dalam menjalankan usahanya. 
Pengalaman berusaha pembesaran ikan patin dalam kolam dapat mempengaruhi usaha yang dikelolanya, dimana dengan lamanya pengalaman usaha wanita tani akan mampu dan mengerti dalam mengelola usaha pembesaran ikan patin dalam kolam. Dengan demikian besar kemungkinan usaha pembesaran ikan patin kolam yang dikelola wanita tani tersebut akan berhasil." Pernyataan ini sependapat dengan pernyataan Asmaida (2018), yaitu pengalaman petani dapat dijadikan tolak ukur untuk pengembangan usaha dimasa yang akan datang. Semakin lama pengalaman berusahanya, maka petani semakin banyak pengetahuannya dalam berusaha. Petani dengan pengalaman berusaha yang cukup lama akan sangat hati-hati dalam menerima dukungan dari pemerintah dan menerima inovasi yang dianggap baru, karena petani akan mempertimbangkan resiko kegagalan bila menerima dukungan dari pemrintah atau menerapkan inovasi tersebut.

\section{Keadaan Usaha Pembesaran Ikan Patin Dalam Kolam}

Luas kolam yang dimaksud pada penelitian ini adalah luas lahan garapan yang dikelola wanita tani dan keluarganya dalam kegiatan usaha pembesaran ikan patin dalam kolam. Untuk lebih jelasnya luas kolam yang diusahakan wanita tani dapat dilihat pada Tabel 5.

Tabel 5. Distribusi Frekuensi Wanita Tani Berdasarkan Luas Kolam Yang Diusahakan di Desa Pudak

\begin{tabular}{cccc}
\hline No & $\begin{array}{c}\text { Distribusi Luas kolam } \\
(\mathrm{m} 2)\end{array}$ & $\begin{array}{c}\text { Frekuensi } \\
\text { (Orang) }\end{array}$ & $\begin{array}{c}\text { Persentase } \\
(\%)\end{array}$ \\
\hline 1. & $10 \times 20$ & 13 & 39,40 \\
2. & $10 \times 15$ & 4 & 12,12 \\
3. & $10 \times 25$ & 2 & 6,06 \\
4. & $20 \times 12$ & 2 & 6,06 \\
5. & $20 \times 15$ & 6 & 18,18 \\
6. & $20 \times 8$ & 2 & 6,06 \\
7. & $25 \times 12$ & 4 & 12,12 \\
\hline
\end{tabular}

Sumber : Olahan data primer, 2020

Berdasarkan Tabel 5 di atas dapat dilihat bahwa sebagaian besar wanita tani luas kolam yang diusahakannya dengan ukuran $10 \times 20 \mathrm{~m}^{2}$ yaitu sebanyak 13 Orang (39,40\%). Sedangkan ukuran kolam yang paling besar adalah $25 \times 12 \mathrm{~m}^{2}$.

Jumlah kolam yang diusahakan wanita tani rata-rata 4 unit. Berdasarkan hasil penelitian dari 33 wanita tani memiliki unit kolam yang beragam yang berkisar antara 1 - 15 unit. Untuk lebih jelasnya dapat dilihat pada Tabel 6.

Tabel 6. Distribusi Frekuensi Wanita Tani Berdasarkan Jumlah Kolam Yang Diusahakan di Desa Pudak

\begin{tabular}{cccc}
\hline No & $\begin{array}{c}\text { Distibusi jumlah kolam } \\
\text { (unit) }\end{array}$ & $\begin{array}{c}\text { Frekuensi } \\
\text { (ORANG) }\end{array}$ & $\begin{array}{c}\text { Persentase } \\
(\%)\end{array}$ \\
\hline 1. & $1-3$ & 10 & 30,30 \\
2. & $4-6$ & 18 & 54,55 \\
3. & $7-9$ & 4 & 12,12 \\
4. & $10-12$ & 1 & 3,03 \\
5. & $13-15$ & 0 & 0,00 \\
6. & $16-18$ & 0 & 0,00 \\
\hline & Jumlah & 33 & 100 \\
\hline
\end{tabular}

Sumber : Olahan data primer, 2020

Dari Tabel 5 di atas terlihat bahwa sebagaian besar jumlah kolam yang diiliki wanita tani berkisar antara 4 - 6 unit yaitu sebanyak 18 orang $(54,55 \%)$. Sedangkan yang memiliki jumlah kolam lebih dari 10 unit adalah sebanyak 1 orang $(3,03 \%)$, hal ini disebabkan karena untuk usaha pembesaran ikan patin dalam kolam memerlukan modal yang relatif besar. Kemampuan modal wanita tani sangat dipengaruhi oleh jumlah kolam yang diusahakan.

\section{Peranan Wanita Tani Pada Usaha Pembesaran Ikan Patin Dalam Kolam}

Dalam rangka peningkatan kesejahteraan hidup masyarakat tani dipedesaan, usaha yang dapat dilakukan adalah memperluas kesempatan ikut sertanya wanita dalam pelaksanaan berbagai kegiatan baik yang menyangkut kehidupan rumah tangga, pengelolaan usaha tani maupun sebagai anggota masyarakat. 
Berdasarkan hasil penelitian bahwa dalam kegiatan usaha pembesaran ikan patin dalam kolam di Desa Pudak menunjukkan adanya kerja sama antara pria dan wanita tani yang telah menjadi suatu kebiasaan yang dilakukan selama ini. Meskipun demikian kegiatan tersebut lebih didominasi oleh tenaga kerja wanita, sehingga memperlihatkan kecenderungan bahwa penyelesaian usaha pembesaran ikan patin dalam kolam tersebut dipercayakan kepada wanita yang dalam hal ini wanita tani atau ibu rumah tangga.

Adapun peranan wanita dalam rangkaian kegiatan proses pembesaran ikan patin dalam kolam yang dilakukan di Desa Pudak, Kecamatan Kumpeh Ulu, Kabupaten Muaro Jambi adalah meliputi kegiatan persiapan kolam, penebaran benih, pemberian pakan, pemeliharaan pematang kolam, dan pemanenan.

\section{A. Persiapan Kolam}

Kegiatan ppersiapan kolam pembesaran ikan patin di Desa Pudak dimulai dengan melakukan kegiatan pengeringan dan pengapuran, pemupukan dan pengisian air. Kegiatan pengeringan kolam yang dilakukan menggunakan mesin penyedot air. Kolam dikeringkan dan diberi kapur kemudian dibiarkan selama 3 hari. Pengeringan kolam dilakukan dengan tujuan untuk membuang semua sisa kotoran/limbah yang ada di dalam kolam pada musim panen sebelumnya, sehingga kolam ikan patin bersih dari segala limbah dan sisa-sisa kotoran.

Kegiatan pengeringan pada persiapan kolam dibarengi dengan kegiatan pengangkatan lumpur menggunakan cangkul agar kedalaman kolam tetap terjaga, sedangkan kegiatan pengapuran bertujuan agar bibit penyakit dan parasit mati terbunuh serta untuk menetralkan $\mathrm{pH}$ kolam. Kegiatan pengangkatan lumpur kolam dan pengapuran umumnya dilakukan oleh pria dan dibantu oleh wanita tani, sedangkan pada kegiatan pemupukan kolam, hampir sepenuhnya dilakukan oleh wanita tani. Pemupukan kolam ikan patin diberikan pada saat benih ikan patin akan di tebar kedalam kolam. Penggunaan pupuk ini bertujuan untuk merangsang pertumbuhan pakan ikan alami seperti Rotifera dan organisme air lain dapat tumbuh di kolam, pupuk yang diberikan secara tidak langsung digunakan oleh ikan. Pupuk yang bisa digunakan adalah pupuk kandang (organik) seperti kotoran hewan dari sapi, kerbau, kambing atau unggas, pupuk buatan (anorganik) maupun pupuk hijau. Pemupukan pada umumnya dilakukan dengan cara menebarkan pupuk secara merata keseluruh permukaan dasar kolam sesuai dengan dosis.

Selanjutnya ahkhir dari kegiatan persiapan kolam adalah kegiatan pengisian air kolam, air yang digunakan dalam kegiatan pembesaran adalah air yang bebas dari logam-logam berat dan tidak tercemar. Kedalaman air dalam kolam minimal $120 \mathrm{~cm}$ karena ikan patin menyukai perairan yang dalam sehingga sebelum penebaran dilakukan kedalaman air sudah mencapai minimal $120 \mathrm{~cm}$. Pengisian air dapat dilakukan secara bertahap agar beban pematang tidak bertambah secara mendadak. Sumber air yang didapat petani yaitu dari aliran kanal dan mata-air yang di endapkan di kolam pengendapan, pengisian air dilakukan dengan cara membuka pintu keluar air yang menuju ke kolam yang sudah dikeringkan dan juga ada yang menggunakan mesin penyedot air.

\section{B. Penebaran Benih}

Kegiatan penebaran benih ikan, kepadatan kolam tergantung pada besarnya benih ikan yang ditebarkan pada kolam pembesaran. Di Desa pudak padat tebar benih yang sudah dilakukan adalah rata-rata sebanyak $15 \mathrm{ekor} / \mathrm{m}^{2}$ dengan benih yang berukuran 2 inch. Penebaran benih umumnya dilakukan oleh wanita tani dan pria sifatnya membantu. Penebaran benih dilakukan di waktu pagi dan sore hari atau pada suhu udara rendah. Sebelum benih ikan di sebarkan di kolam dilakukan proses aklimatisasi agar ikan tidak kaget dan langsung bisa menyesuaikan diri dengan lingkungan yang baru. Proses aklimatisasi ini adalah dengan membiarkan ikan patin keluar dengan sendirinya dari wadah pengangkutan benih ke kolam. Proses ini bisa dipercepat dengan mencampurkan secara sedikit demi sedikit air kolam ke air wadah pengangkutan. Benih yang diperoleh petani pembesaran berasal dari petani pembibitan yang berada di lokasi penelitian. Tingkat mortalitas benih sebesar 6-7 persen.

\section{Pemberian Pakan Ikan}

Kegiatan pemberian pakan ikan di Desa Pudak hampir sepenuhnya dilakukan oleh wanita tani. Pemberian pakan ikan pada proses pembesaran ikan patin di kolam sangat mutlak untuk memacu pertumbuhan. Pakan tambahan itu berupa pelet atau sisa-sisa kegiatan dapur. Jumlah pakan tambahan biasanya 3-4\% dari bobot total ikan per hari. Pelet ini ada yang dibuat sendiri (pelet lokal) dan ada pula pelet buatan pabrik (pelet komersial). Pakan tambahan lainnya yang juga bisa diberikan adalah limbah ikan, udang-udangan, moluska dan bekicot. Pemberian pakan jenis ini sesuai dengan pakan ikan patin di alam..

Pemberian pakan buatan dilakukan tiga sampai empat kali sehari (pagi, siang, sore dan malam). Dalam pelaksanaannya pemberian pakan buatan ini baru dihentikan setelah hampir 25\% dari ikan yang ada telah meninggalkan tempat pemberian pakan. Hal ini menandakan bahwa sebagian besar ikan patin sudah mulai kenyang. Jarak waktu antara pemberian pakan yang satu dengan pemberian pakan berikutnya adalah 4 jam karena biasanya ikan kembali lapar setiap 3-4 jam setelah makan terakhir dan kegiatan pemberian pakan umumnya dilakukan oleh wanita tani. 


\section{Pembersihan Pematang Kolam}

Kegiatan pembersihan pematang kolam di Desa Pudak dilakukan oleh wanita tani dan pria. Pembersihan pematang kolam ini seperti membersihkan gulma/rumput yang tumbuh disepanjang pematang kolam menggunakan parang atau sabit, membuang sampah-sampah yang masuk ke dalam kolam menggunakan serokan.

\section{E. Panen}

Panen merupakan kegiatan akhir dari suatu produksi. Di Desa Pudak panen ikan patin dilakukan oleh wanita tani dan pria. Pemanenan dilakukan bila ikan patin sudah dipelihara di kolam pembesaran selama enam bulan. Pada umur ini ikan patin biasanya sudah mencapai ukuran konsumsi. Semakin besar ukuran benih yang ditebarkan semakin singkat masa pemeliharaannya. Lamanya waktu panen ikan patin tergantung pada banyaknya benih ikan yang ditebar dan ukuran kolam ikan. Semakin banyak benih ikan yang ditebar dan luasnya ukuran kolam, maka semakin lama waktu panen yang diperlukan dan sedikit benih yang ditebar dan kecil ukuran kolam maka semakin cepat waktu panen.

Peran wanita pada usaha pembesaran ikan patin dalam kolam dapat dikategorikan tinggi karena pada setiap alokasi kegiatan hampir sepenuhnya pekerjaan tersebut dilakukan oleh wanita tani.

\section{Curahan Waktu Kerja Wanita Tani Pada Usaha Pembesaran Ikan Patin Dalam Kolam}

Alokasi curahan waktu kerja dalam kegiatan usaha pembesaran ikan patin dalam kolam di Desa Pudak, antara lain yaitu persiapan kolam (pengeringan, pemupukan dan pengapuran serta pengisian air), pemberian pakan ikan, pembersihan pematang kolam, dan panen. Alokasi curahan waktu kerja dalam penelitian ini adalah besaran curahan jam kerja per periode produsi yang dicurahkan oleh anggota rumah tangga dalam usaha pembesaran ikan patin kolam. Satu periode produksi adalah setara dengan 6 bulan. Untuk lebih jelasnya alokasi curahan waktu kerja dalam usaha pembesaran ikan patin kolam dapat dilihat pada Tabel 7 .

Tabel 7. Curahan Waktu Kerja Pada Usaha Pembesaran Ikan Patin Kolam (Jam/Periode Produksi) di Desa Pudak.

\begin{tabular}{|c|c|c|c|c|}
\hline No. & Uraian & Wanita & Pria & Jumlah \\
\hline \multirow[t]{4}{*}{1} & Persiapan Kolam & & & \\
\hline & Rata-rata & 31,48 & 24,88 & 56,36 \\
\hline & Maksimum & 48,0 & 40,0 & 72,0 \\
\hline & Minimum & 16,0 & 6,0 & 24,0 \\
\hline \multirow[t]{4}{*}{2} & Penebaran Benih & & & \\
\hline & Rata-rata & 4,12 & 0,36 & 4,48 \\
\hline & Maksimum & 12,0 & 2,0 & 15,0 \\
\hline & Minimum & 2,0 & 0,0 & 2,0 \\
\hline \multirow[t]{4}{*}{3} & Pemberian Pakan & & & \\
\hline & Rata-rata & 338,18 & 3,88 & 342,06 \\
\hline & Maksimum & 540,0 & 64,0 & 604,0 \\
\hline & Minimum & 180,0 & 0,0 & 180,0 \\
\hline \multirow[t]{4}{*}{4} & Pembersihan Pematang Kolam & & & \\
\hline & Rata-rata & 30,91 & 3,39 & 34,30 \\
\hline & Maksimum & 48,0 & 48,0 & 96,0 \\
\hline & Minimum & 24,0 & 0,0 & 24,0 \\
\hline \multirow[t]{4}{*}{5} & Panen & & & \\
\hline & Rata-rata & 3,36 & 7,00 & 10,36 \\
\hline & Maksimum & 6,0 & 9,0 & 14,0 \\
\hline & Minimum & 2,0 & 3,0 & 5,0 \\
\hline
\end{tabular}

Sumber : Olahan data primer, 2020

Dari data pada Tabel 6 di bawah, diketahui bahwa curahan waktu kerja pada kegiatan persiapan kolam (pengeringan kolam, pengapuran, pemupukan, dan pengisian air) berkisar antara $0-48,0$ jam per periode produksi. Rata-rat curahan waktu kerja wanita relatif lebih tinggi dibandingkan pria. Jika curahan waktu kerja secara keseluruhan pada kegiatan persiapan kolam digabungkan antara wanita dan pria, ternyata kisaran ratarata berada di antara 24,0 - 72,0 jam per periode produksi atau rata-rata sekitar 56,36 jam per periode produksi. Curahan waktu kerja tertinggi diberikan oleh wanita terutama dalam melakukan kegiatan pemupukan dan pengapuran, sedangkan pria hanya banyak terlibat dalam kegiatan pencangkulan dasar kolam."Pada kegiatan penebaran benih, curahan waktu kerja berkisar antara $0-12,0$ jam per periode produksi. Rataan curahan waktu kerja wanita relatif lebih tinggi dibandingkan pria. Curahan waktu kerja secara keseluruhan atau curahan waktu 
kerja wanita dan pria digabungkan, ternyata kisaran rata-rata berada di antara 2,0 - 15,0 jam per periode produksi atau rata-rata sekitar 4,48 jam per siklus.

Pada kegiatan pemberian pakan, curahan waktu kerja berkisar antara $0,0-540,0$ jam per periode produksi. Rataan curahan waktu kerja wanita relatif lebih tinggi dibandingkan pria. Jika curahan waktu kerja secara keseluruhan pada kegiatan pemberian pakan digabungkan antara wanita dan pria, ternyata kisaran rata-rata berada di antara 180,0 - 602,0 jam per periode produksi atau rata-rata sekitar 342,06 jam per periode produksi.

Pada kegiatan pembersihan pematang kolam, curahan waktu kerja berkisar antara 0,0 - 48,0 jam per periode produksi. Rataan curahan waktu kerja wanita relatif lebih tinggi dibandingkan pria. Jika curahan waktu kerja secara keseluruhan pada kegiatan pembersihan pematang kolam digabungkan antara wanita dan pria, ternyata kisaran rata-rata berada di antara 24,0 - 96,0 jam per periode produksi atau rata-rata sekitar 34,30 jam per periode produksi.

Pada kegiatan panen, curahan waktu kerja berkisar antara 2,0 - 9,0 jam per periode produksi. Dalam hal ini rataan curahan waktu kerja wanita relatif lebih rendah dibandingkan pria. Jika curahan waktu kerja secara keseluruhan pada kegiatan panen digabungkan antara wanita dan pria, ternyata kisaran rata-rata berada di antara $5,0-14,0$ jam per periode produksi atau rata-rata sekitar 10,36 jam per periode produksi.

Selanjutnya alokasi curahan waktu kerja dari semua alokasi kegiatan pada usaha pembesaran ikan patin dalam kolam, curahan waktu kerja tertinggi terjadi pada kegiatan pemberian pakan yaitu sebesar 342,06 jam per periode produksi dan terendah pada kegiatan penebaran benih yaitu sebesar 4,48 jam per periode produksi. Sedangkan rata-rata curahan waktu kerja secara keseluruhan pada kegiatan pembesaran ikan patin kolam, yang dimulai dari kegiatan persiapan kolam, penebaran benih, pemberian pakan, pembersihan pematang kolam dan panen menghabiskan waktu sebesar 447,56 jam per periode produksi.

Wanita tani (ibu rumah tangga) di Desa Pudak, curahan waktu kerjanya pada usaha pembesaran ikan patin kolam sangat tinggi dibandingkan dengan pria, terlihat bahwa hampir seluruh kegiatan pada usaha pembesaran ikan patin dalam kolam di Desa Pudak sepenuhnya dilakukan oleh wanita tani (ibu rumah tangga). Hasil penelitian ini sejalan dengan penelitian Asmaida (2009), yang menyatakan peranan wanita tani dalam berusaha budidaya ikan patin kolam di Desa Pudak dikategorikan tinggi karena wanita tani di daerah tersebut mempunyai kepercayaan yang tinggi terhadap usaha budidaya ikan patin kolam dapat meningkatkan ekonomi rumah tangganya, dan wanita taninya berperann aktif dengan mencurahkan waktu kerjanya yang tinggi.

\section{Kontribusi Curahan Waktu Kerja Wanita Tani Pada Usaha Pembesaran Ikan Patin Dalam Kolam}

Kontribusi curahan waktu kerja wanita tani adalah tenaga kerja yang dicurahkan wanita (ibu rumah tangga) pada kegiatan usaha pembesaran ikan patin dalam kolam yang diukur dalam persentase (\%). Sedangkan total curahan waktu kerja pada usaha pembesaran ikan patin dalam kolam adalah curahan waktu kerja pada semua kegiatan usaha pembesaran ikan patin dalam kolam selama proses produksi yang berasal dari tenaga kerja wanita (ibu rumah tangga) dan pria, seperti terlihat pada Tabel 8.

Tabel 8. Rataan Kontribusi Curahan Waktu kerja Wanita Tani Pada Usaha Pembesaran Ikan Patin Dalam Kolam

\begin{tabular}{|c|c|c|c|c|c|c|c|}
\hline \multirow[b]{2}{*}{ No } & \multirow[b]{2}{*}{$\begin{array}{l}\text { Uraian } \\
\text { Jenis Kegiatan }\end{array}$} & \multicolumn{2}{|c|}{ Wanita } & \multicolumn{2}{|c|}{ Pria } & \multicolumn{2}{|c|}{ Jumlah Total } \\
\hline & & $\begin{array}{l}\text { Jumlah }(\mathrm{Jam} / \\
\text { periode })\end{array}$ & $\begin{array}{l}\text { Persentase } \\
\quad(\%)\end{array}$ & $\begin{array}{l}\text { Jumlah }(\mathrm{Jam} / \\
\text { periode) }\end{array}$ & $\begin{array}{l}\text { Persentase } \\
\text { (\%) }\end{array}$ & $\begin{array}{l}\text { Jumlah } \\
\text { (Jam/ } \\
\text { periode) }\end{array}$ & Persentase (\%) \\
\hline 1 & Persiapan Kolam & 31,48 & 7,03 & 24,88 & 5,56 & 56,36 & 12,59 \\
\hline 2 & Penebaran Benih & 4,12 & 0,92 & 0,36 & 0,08 & 4,48 & 1,00 \\
\hline 3 & Pemberian Pakan & 338,18 & 75,56 & 3,88 & 0,87 & 342,06 & 76,42 \\
\hline 4 & $\begin{array}{l}\text { Pembersihan pematang } \\
\text { kolam }\end{array}$ & 30,91 & 6,91 & 3,39 & 0,76 & 34,3 & 7,66 \\
\hline 5 & Panen & 3,36 & 0,75 & 7 & 1,56 & 10,36 & 2,31 \\
\hline & Jumlah & 408,06 & 91,17 & 39,52 & 8,83 & 447,58 & 100,00 \\
\hline
\end{tabular}

Sumber : Olahan data primer, 2020

Berdasarkan Tabel 7 di atas dapat dilihat bahwa wanita tani sebagai ibu rumah tangga memberikan waktu kerjanya yang paling tinggi dibandingkan dengan pria pada usaha pembesaran ikan patin dalam kolam di Desa Pudak. Kegiatan yang dilakukan oleh wanita tani dalam usaha pembesaran ikan patin kolam dengan jumlah jam kerja paling besar adalah tercurah pada kegiatan pemberian pakan yaitu rata-rata selama 338,18 jam/periode produksi atau sebesar $75,56 \%$ dan waktu kerja yang paling kecil yaitu rata-rata 4,12 jam/periode produksi atau sebesar $0,92 \%$ digunakan untuk kegiatan penebaran benih. sedangkan waktu kerja pria yang terbesar dialokasikan untuk kegiatan persiapan kolam yaitu selama 24,88 jam/periode produksi atau sebesar 5,56\% dan yang terkecil adalah pada kegiatan penebaran benih yaitu $0,36 \mathrm{jam} /$ periode produksi atau sebesar $0,08 \%$. 
Sumber tenaga kerja yang dicurahakan pada usaha pemebesaran ikan patin dalam kolam di Desa Pudak bersumber dari tenaga kerja ibu rumah tangga yang berperan sebagai wanita tani dengan kontribusi waktu kerjanya sebesar 408,06 jam/periode produksi atau sebesar 91,17\%. Jumlah curahan jam kerja wanita sangat besar jika dibandingkan dengan waktu kerja pria yaitu sebesar 8,83\%. Hal ini sejalan dengan pernyataan Sayogyo (1993), curahan waktu kerja wanita dalam proses pembangunan bukanlah sekadar kewajiban moral tetapi adalah suatu tindakan yang tepat untuk memanfaatkan sumberdaya manusia yang tidak kecil jumlahnya."Ihrom (1995), menyatakan bahwa kecenderungan yang terjadi saat ini sudah mulai terlihat bahwa kontribusi wanita dalam menunjang ekonomi keluarga cukup besar. Hal tersebut karena sudah semakin banyaknya wanita yang memasuki lapangan kerja. Dengan demikian dapat dikatakan bahwa kontribusi wanita dalam pemenuhan hak fisik keluarga semakin besar.

\section{KESIMPULAN}

1. Peranan wanita tani pada usaha pembesaran ikan patin dalam kolam di Desa Pudak Kecamatan Kumpeh Ulu Kabupaten Muaro Jambi cukup tinggi, wanita tani hampir sepenuhnya terlibat antara lain pada kegiatan persiapan kolam (pengeringan kolam, pengapuran, pemupukan dan pengisian air), kegiatan penebaran benih, kegiatan pemberian pakan, kegiatan pembersihan pematang kolam, dan kegiatan panen.

2. Rataan curahan waktu kerja wanita tani pada usaha pembesaran ikan patin dalam kolam untuk kegiatan persiapan kolam (pengeringan kolam, pengapuran, pemupukan dan pengisian air) adalah selama 31,48 jam per periode produksi, kegiatan penebaran benih selama 4,12 jam per periode produksi, kegiatan pemberian pakan selama 338,18 jam per periode produksi, kegiatan pembersihan pematang kolam 30,91 jam per periode produksi, dan kegiatan panen selama 3,36 jam per periode produksi.

3. Kontribusi curahan waktu kerja wanita tani pada usaha pembesaran ikan patin dalam kolam sebesar $91,17 \%$, semestara sisanya $8,83 \%$ adalah curahan waktu kerja pria.

\section{DAFTAR PUSTAKA}

Afriantoni, 1993, Faktor-faktor Yang Mempengaruhi Partisipasi Wanitatani Terhadap Kelompok Tani Padi Sawah di Kecamatan Sekernan Kabupaten Batanghari. Skripsi Fakultas Pertanian Universitas Jambi.

Asmaida, 2009. Hubungan Tingkat Pengetahuan dan Tingkat Kepercayaan Dengan Curahan Jam kerja Wanita Tani Pada Usaha Budidaya Ikan Patin kolam (Studi Kasus Di Desa Pudak Kecamatan Kumpeh Ulu Kabupaten Muaro Jambi. Jurnal Ilmiah Universitas Batanghari Jambi. Vol 9 No. 1 Februari 2009.

Asmaida, 2018. Manfaat Ekonomi Yang Diterima Petani Peserta Program Gerakan Pakan Ikan Mandiri (Gerpari) Dalam Usaha Budidaya Ikan (Studi Kasus Di Desa Jembatan Mas Kecamatan Pemayung Kabupaten Batanghari). Jurnal MEA (Media Agribisnis) Program studi Agribisnis Fakultas Pertanian Universitas Batanghari Jambi. Vol 3 No. 2 Oktober 2018.

Asmaida, at all, 2019. Realitionship Between Perception And Consumers' Preferences Of Patin Fhis. Jurnal International Journal of Scientific \& Technology Vol 8 Issue 10 Oktober 2019 Hal Vol 8 Issue 10 Oktober 2019 Hal 2689-2693 Edition - ISSN 2277-8616.

BPS Provinsi Jambi, 2019. Provinsi Jambi Dalam Angka. Jambi.

Hernanto, F. 1988. Ilmu Usaha Tani Sandaya. Jakarta.

Ihromi, T.O, 1995. Kajian Wanita Dalam Pembangunan Yayasan Obor Indonesia (YOI). Jakarta.

Kementrian Kelautan dan Perikanan Republik Indonesia, 2019. Laporan Tahunan Tahun 2019. Kementrian Kelautan dan Perikanan Republik Indonesia. Jakarta.

Sajogyo dan Pudjiwati, S, 1992. Sosiologi Pedesaan Jilid II. Gajah Mada University Press. Jakarta.s

Simatau, 2001. Gender dan Pengelolaan Sumber Daya Alam; Sebuah Panduan Analisis. Galang Printika. Yogyakarta.

Singarimbun. M dan S. Efendi, 1982. Metode Penelitian Survei. LP3ES. Jakarta.

Sri Ayu Kurniati, 2016. Analisis Partisipasi Tenaga Kerja Wanita dan Kontribusi Pendapatan (Studi Kasus Agroindustri Patin Desa Koto Mesjid Kabupaten Kampar, Provinsi Riau). Jurnal Dinamika Pertanian Volume XXXII Nomor 1 April 2016 (57-64) P: ISSN 0215-2525 E: ISSN 2549-7960

Statistik Budidaya Perikanan, 2018. Statistik Dinas Kelautan dan Perikanan Provinsi Jambi. Jambi.

Sudarta, W, 2003. Peranan Wanita Dalam Pembangunan Berwawasan Gender. Jurnal Studi Jender SRIKANDI.

Suratiyah, K. 2003. Usahatani. Diktat. Diterbitkan Untuk Kalangan Sendiri. Program Studi Agribisnis. Jurusan Sosial Ekonomi Pertanian Fakultas Pertanian UGM. Yogyakarta.

Ulber Silalahi, 2010. Metode Penelitian Sosial. PT. Refika Aditama. Bandung.

Winarno, S. 1994. Pengantar Penelitian Ilmiah. Penerbit Kanisius Tarsito. Bandung. 